\title{
OVER-SUMMERING OF WHEAT STRIPE RUST (Puccinia striiformis f.sp. tritici) IN THE CALIFORNIA CENTRAL VALLEY: A CASE STUDY
}

\author{
Huib Tollenaar ${ }^{*}$
}

To study the over-summering of wheat stripe rust (Puccinia striiformis f.sp. tritici) in the California Central Valley (CCV), temperature records from various locations in the CCV during the period 1950-2009 were examined for the occurrence of lethal maximum temperatures for the uredinia and uredinio-mycelium of this fungus. The lethal upper threshold temperature for the uredinial stage of P.s. tritici, estimated to be $40.5^{\circ} \mathrm{C}$ on the basis of data published elsewhere, and the sum, accumulated during ten consecutive days, of the respective lethal temperature quotients (ALTQ 10 ), accounting for the partial lethal effect of the daily ambient temperatures between 30 and $40.5^{\circ} \mathrm{C}$ on the uredinial stage of P.s. tritici, were used as yardsticks for thermal lethality. The results indicate that, in these $60 \mathrm{yr}$, the uredinia and the uredinio-mycelium of P.s. tritici could not possibly have over-summered at any of the locations studied. The Sierra Nevada Mountains, together with the Tulelake Basin and the coastal zone of the Pacific Ocean are the only two areas in California with appropriate environmental conditions for the summer-survival of the uredinial stage of stripe rust. Therefore, it is presumed that the inoculum for the initial infections of P.s. tritici in wheat fields in the CCV during the following growing season originates in either one or both of these areas, although, a potential third source of inoculum for the initial infections of stripe rust in the CCV could also be involved. Namely, the possible presence of telia with viable teliospores of P.s. tritici in autumn on straw of the threshed wheat fields or on volunteer wheat plants in the $\mathrm{CCV}$, in conjunction with the accidental concurrence of nearby stripe rust susceptible barberry (Berberis spp.), could lead to the development of alternative, endogenous sources of inoculum in the CCV.

Key words: Yellow rust, epidemiology, lethal temperature, Triticum aestivum.

$\mathrm{T}$ he California Central Valley (CCV), also called the Sacramento-San Joaquin Valley, consists of an extensive area, almost completely enclosed by the mountains of the Coast Ranges and the Sierra Nevada Mountains, with the Coast Ranges minimizing the moderating influence of the Pacific Ocean on maximum daily summer temperatures. According to the temperature records of the National Climatic Data Center (NCDC) in Asheville, North Carolina, USA, all locations in this valley have closely similar maximum temperatures in summer. The daily maximum temperatures in the $\mathrm{CCV}$ are normally very high from May through October and it was therefore understood to be unfit for over-summering of the uredinial stage of stripe rust (Tollenaar and Houston, 1967). Nevertheless, this option was discarded by Line $(1976$; 2002) after detecting, in November 1973, volunteer wheat (Triticum aestivum L.) plants with stripe rust infections in an irrigated orchard in the Sutter Basin of the Sacramento Valley, the northern half of the CCV. Based on this evidence alone, it was claimed that the uredinial stage of P.s. tritici could over-summer in certain

${ }^{1}$ Tarrragona 359, Villa Los Colonos, Chillán, Chile. "Corresponding author (huibtollenaar@hotmail.com). Received: 20 November 2011.

Accepted: 20 April 2012. parts of the $\mathrm{CCV}$, where this infection could then act in autumn as a primary source of inoculum. This claim is now generally accepted (Chen et al., 2002; Line, 2002; Chen, 2005), but not without serious doubts since no live specimens of P.s. tritici were ever recovered from these wheat plants with uredinial stripe rust lesions in the critical time span between May and October (R.F. Line, Washington State University, Pullman, Washington, USA; personal communication). Moreover, there are no other reports verifying the over-summering of stripe rust in the CCV.

To elucidate the extent of the over-summering of the uredinial stage of P.s. tritici in the California Central Valley, a study was carried out evaluating the occurrence of lethal maximum summer temperatures for wheat stripe rust in this area. For this purpose, I compared data derived from the investigation of Dennis (1987) about the effect of high temperatures on the development and survival of uredinia and the uredinio-mycelium of P.s. tritici to the available temperature records of various locations in the California Central Valley.

\section{MATERIALS AND METHODS}

An estimate of the lethal upper threshold temperature of P.s. tritici is essential for an evaluation of its ability to 
over-summer in a specific geographic area. By definition, exposure to the lethal upper threshold temperature or over causes instant death in P.s. tritici. This temperature can only be determined by means of extrapolation of exposure time measurements taken at temperatures slightly below the lethal upper threshold temperature. A requirement for the latter temperatures is that they must still be lethal to the fungus, but only after a certain exposure time. Dennis (1987) furnishes numerous data on the effect of the exposure time to high constant as well as fluctuating temperatures on the survival of latent and sporulating infections of the uredinial stage of P.s. tritici. These data have been used in the following analysis.

The results of experiments on the exposure time to high temperatures conducted in controlled environments with constant temperatures are not necessarily the same as those from experiments conducted in natural environments with fluctuating daily temperatures. For this reason, only data from the temperature cycle experiments of Dennis (1987), with daily temperatures fluctuating between a maximum and minimum, have been taken into account for further analysis as those conditions resemble more closely field conditions. Each cycle experiment, which lasted until the death of the pathogen, consisted of daily exposure of latent and sporulating infections to a particular constant maximum temperature for a specific number of hours and the rest of the day to a constant minimum temperature of $17^{\circ} \mathrm{C}$. Treatments were daily cycles of $12 \mathrm{~h}$ at $30^{\circ} \mathrm{C} / 12 \mathrm{~h}$ at $17^{\circ} \mathrm{C}, 6 \mathrm{~h}$ at $35^{\circ} / 18 \mathrm{~h}$ at 17 ${ }^{\circ} \mathrm{C}$, or $1 \mathrm{~h}$ at $40^{\circ} \mathrm{C} / 23 \mathrm{~h}$ at $17^{\circ} \mathrm{C}$, respectively. On the basis of Figure 2 from Dennis (1987), the total number of hours of exposure to the respective maximum temperature until the death of P.s. tritici was calculated for each treatment. Subsequently, these data (Table 1) were subjected to a simple linear regression analysis. The estimated values of the abscissa, regression coefficient and coefficient of determination for the sporulating infection were 40.66, -8 , and 0.9967 , respectively, whereas the corresponding values for the latent infection were $40.44,-5.7$, and 0.9991 , respectively. This means that the estimated lethal upper threshold temperatures for the sporulating infection and the latent infection of the uredinial stage of P.s. tritici are 40.66 and $40.44{ }^{\circ} \mathrm{C}$, respectively.

The eventual fate of the fungus in the region during summer months with high maximum temperatures

Table 1. Duration of lethal exposure time at different temperatures for sporulating and latent infections of the uredinial stage of Puccinia striiformis f.sp. tritici. Duration of exposure was calculated by multiplying the number of cycles (d) with the hours of exposure to the respective maximum temperature in each cycle. Data were retrieved from Figure 2 of Dennis (1987).

\begin{tabular}{lcc}
\hline & Sporulating infection & Latent infection \\
\hline & Duration of exposure $($ cycles $\times \mathrm{h} /$ cycle $)$ \\
$30^{\circ} \mathrm{C}$ & $84(=7 \times 12)$ & $60(=5 \times 12)$ \\
$35^{\circ} \mathrm{C}$ & $48\left(=8^{*} \times 6\right)$ & $30(=5 \times 6)$ \\
$40^{\circ} \mathrm{C}$ & $4(=4 \times 1)$ & $3(=3 \times 1)$ \\
\hline
\end{tabular}

"Datum obtained by extrapolation. depends to a large degree on the survival of latent infections of the uredinial stage. Undoubtedly, under appropriate environmental conditions, spores from sporulating uredinia produce new latent infections in susceptible wheat. But the lifetime of sporulating infections is limited by the senescence of its host tissue. Whereas, when high ambient temperatures prevent latent infections from developing into new sporulating uredinia to replace the preceding ones, the rust will disappear from the area. Therefore attention has been focused solely on the survival of latent infections, although the very slight difference between the estimated upper threshold temperature for the sporulating infection and the latent infection hardly warrants any distinction. Furthermore, from here on, the upper lethal threshold temperature of the latent infection of the uredinial stage is considered to be $40.5^{\circ} \mathrm{C}$.

The results of the regression analysis, relating the exposure time to high temperatures and the death of latent P.s.tritici infections, can be summarized in the following equation:

$$
t=(40.5-T) \times 5.7
$$

where $t$ represents hours of exposure to temperature $T$ (30 $>T<40.5^{\circ} \mathrm{C}$ ) needed to kill a latent infection. Equation [1] can be rearranged in a more general form as:

$$
L T Q=\frac{t}{(40.5-T) \times 5.7}
$$

From Equation [1] it follows that with a lethal temperature quotient (LTQ) of 1 or more in Equation [2], the critical number of hours of exposure to the respective lethal temperature $\left(30^{\circ}>T<40.5^{\circ} \mathrm{C}\right)$, causing $P$.s.tritici to succumb to thermal stress, has been reached or surpassed, respectively. Conversely, an interval shorter than the critical time span of exposure to lethal temperatures in the $30-40.5^{\circ} \mathrm{C}$ range allows for its survival. In the latter case, Equation [2] will then yield a LTQ $<1$, which represents the relative size of the partial lethal impact during that day on the latent infection of P.s. tritici. The magnitude of the accumulative lethal impact of high temperatures on stripe rust infections in wheat during a 10 -d period was found to be determinative as to its demise in an area (Tollenaar and Houston, 1967; Zeng and Luo, 2006). In other words, if the accumulative sum of daily LTQs of 10 consecutive days $\left(\mathrm{ALTQ}_{10}\right)$ is equal to or greater than 1 , the latent uredinial infections of P.s. tritici will have ceased to exist in that respective area.

The shape of the daily temperature graphic of an outside environment normally varies between a slightly sinuate curve and an almost straight ascending line between the daily minimum $\left(T_{\min }\right)$ and maximum temperature $\left(T_{\max }\right)$ in the first part of the day, and vice versa in the second part, viz. a descending line between this $T_{\max }$ and the $T_{\min }$ of the next day. But any indications of the shape of the daily temperature graph or the exact hours at which minimum and maximum temperatures occur are generally not mentioned in temperature records. Here, it 
is assumed to be a straight line connecting $T_{\min }$ observed in the morning with $T_{\max }$ in the afternoon, separated by 12 $\mathrm{h}$, and also a straight line connecting the same $T_{\max }$ with $T_{\min }$ observed $12 \mathrm{~h}$ later, in the morning of the next day. This approximates most situations during the summer months and allows us to draw upon a simple mathematical procedure to estimate the impact of high temperatures on P.s. tritici every $12 \mathrm{~h}$. At times, a small underestimation of the effect of temperature in the high temperature range (30-40.5 ${ }^{\circ} \mathrm{C}$ ) can occur due to the slightly convex form of this part of the real temperature curve.

Exposure of latent infections of stripe rust in wheat to an environment with a daily temperature cycle fluctuating between a minimum temperature of $17{ }^{\circ} \mathrm{C}$ or below and a maximum temperature level in the range of 30-40.5 ${ }^{\circ} \mathrm{C}$ produces a fraction of the lethal high temperature effect (LTQ) on the pathogen every day. Its size can be calculated with Equation [2], where $t$ represents the time span in the first half of the day between the moment the environmental temperature reaches $30{ }^{\circ} \mathrm{C}$ and the occurrence of the maximum temperature $\left(<40.5^{\circ} \mathrm{C}\right)$ of that day, and $T$ the mean temperature during time $t$. The same procedure is repeated for the second half of the day for the time span between the maximum temperature and the moment the environmental temperature drops below $30{ }^{\circ} \mathrm{C}$. The size of the time span $t$ is expressed by the equation:

$$
t=12 \times \frac{\left(T_{\max }-30\right)}{\left(T_{\max }-T_{\min }\right)}
$$

whereas the mean temperature $T$ during time $t$ is

$$
T=\frac{\left(T_{\max }+30\right)}{2}
$$

By replacing $\mathrm{t}$ and $\mathrm{T}$ in Equation [2] with Equations [3] and [4], respectively, we obtain:

$$
L T Q=\frac{24 \times\left(T_{\max }-30\right)}{5.7 \times\left(T_{\max }-T_{\min }\right) \times\left(51-T_{\max }\right)}
$$

for the first half of the day. The LTQ for the second half of the day is calculated by replacing $T_{\min }$ of that day with the $T_{\min }$ of the next day. This procedure is repeated for the next $9 \mathrm{~d}$. The sum of the 20 LTQs thus obtained represents the corresponding $\mathrm{ALTQ}_{10}$. A simpler but less accurate method to calculate the ALTQ ${ }_{10}$ is based on replacing $T_{\text {min }}$ and $T_{\max }$ in Equation [5] by the mean daily minimum $\left(T_{\text {mean }}\right.$ min $)$ and maximum $\left(T_{\text {mean max }}\right)$ temperatures of that $10-\mathrm{d}$ period, respectively, and multiplying this equation by 20 to account for the period of 20 half days, which gives:

$$
A L T Q_{10}=\frac{480 \times\left(T_{\text {mean } \max }-30\right)}{5.7 \times\left(T_{\text {mean max }}-T_{\text {mean min }}\right) \times\left(51-T_{\text {mean max }}\right)} \text { [6] }
$$

For a comparative analysis of Equations [5] and [6], two randomly selected data sets on the maximum and minimum temperatures during $10 \mathrm{~d}$ in the summer of 2010 at each of six locations in the CCV were taken from the records of the National Climatic Data Center (NCDC) at Asheville, North Carolina. The results (Table $2)$ point to a significant $(\mathrm{P}<0.001)$ underestimation of the
Table 2. Comparison of the accumulated sum of lethal temperature

\begin{tabular}{|c|c|c|c|c|c|}
\hline Location & Period & $\begin{array}{c}\text { Mean } \\
\mathrm{T}_{\max }\end{array}$ & $\begin{array}{c}\text { Mean } \\
\mathrm{T}_{\min }\end{array}$ & \multicolumn{2}{|c|}{ ALTQ $_{10}{ }^{*}$} \\
\hline & 2010 & - & $\mathrm{C}-$ & Equation [5] & Equation [6] \\
\hline Colusa & $6 / 20-6 / 29^{* *}$ & 33.4 & 16.4 & 1.226 & 0.957 \\
\hline Colusa & $9 / 25-10 / 4^{* *}$ & 34.3 & 12.3 & 1.027 & 0.986 \\
\hline Oroville & $7 / 2-7 / 11^{* * *}$ & 34.4 & 13.4 & 1.210 & 1.063 \\
\hline Oroville & $7 / 20-7 / 29^{* *}$ & 34.5 & 13.2 & 1.173 & 1.078 \\
\hline Davis & $6 / 21-6 / 30^{* *}$ & 33.7 & 14.3 & 1.097 & 0.928 \\
\hline Davis & $7 / 15-7 / 24^{* *}$ & 34.5 & 13.4 & 1.215 & 1.088 \\
\hline Winters & $7 / 4-7 / 13^{* *}$ & 35.3 & 15.9 & 1.487 & 1.465 \\
\hline Winters & $7 / 20-7 / 29^{* *}$ & 34.2 & 13.7 & 1.073 & 1.027 \\
\hline Los Banos & $8 / 1-8 / 10^{* *}$ & 33.9 & 15.6 & 1.149 & 1.022 \\
\hline Los Banos & $8 / 13-8 / 22^{* * *}$ & 34.3 & 14.3 & 1.151 & 1.084 \\
\hline
\end{tabular}
quotients over a 10-d period $\left(\mathrm{ALTQ}_{10}\right)$ calculated with Equation [5] and Equation [6]. Based on the temperature records (National Climatic Data Center) from six locations in the California Central Valley in 2010.

$\mathrm{ALTQ}_{10}$ values calculated with Equation [6]. However, the principal aim was to determine if $\mathrm{ALTQ}_{10}>1$ for the respective 10-d period, which is the case in seven out of the ten data sets. In the overall analysis, Equation [6] was therefore used, but with a data set yielding $0.9<\mathrm{ALTQ}_{10}$ $<1$, the calculation was repeated with Equation [5] for confirmation.

Among all the locations in the CCV, only a small number have complete long-term NCDC temperature records available. Nine locations were selected, two of which, Coalinga and Los Banos, are in the southern half of the $\mathrm{CCV}$ and the other six in the northern part, also called the Sacramento Valley. More locations in the northern part were selected because wheat stripe rust infections usually appear there first. The geographic locations and corresponding NCDC file numbers are as follows, Chico:

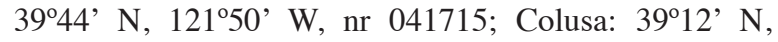
$120^{\circ} 00^{\prime} \mathrm{W}, \mathrm{nr} 041948$; Davis: $38^{\circ} 33^{\prime} \mathrm{N}, 121^{\circ} 45^{\prime} \mathrm{W}, \mathrm{nr}$ 042294; Winters: 38³1' N, 121 ${ }^{\circ} 58^{\prime} \mathrm{W}$, nr 049742; Los Banos: $37^{\circ} 03^{\prime} \mathrm{N}, 120^{\circ} 50^{\prime} \mathrm{W}$, nr 045118; and Coalinga: $36^{\circ} 08^{\prime} \mathrm{N}, 120^{\circ} 21^{\prime} \mathrm{W}, \mathrm{nr} 041864$. In the second part of this study, the incomplete temperature records at Chico were replaced by those from nearby Oroville: $39^{\circ} 31^{\prime} \mathrm{N}, 121^{\circ} 33^{\prime}$ W, nr 046521, or Oroville Dam: 39 $53^{\prime} \mathrm{N}, 121^{\circ} 48^{\prime} \mathrm{W}$, nr 046527, and data sets from the location Willows: $39^{\circ} 31^{\prime}$ $\mathrm{N}, 122^{\circ} 37^{\prime} \mathrm{W}, \mathrm{nr}$ 049699, were also considered.

\section{RESULTS AND DISCUSSION}

Table 3 shows the data from the survey of days with a maximum temperature $>40.5^{\circ} \mathrm{C}$ or in the absence of this phenomenon, 10-d periods with an $\mathrm{ALTQ}_{10}>1$ from May to October of 1950-2009 at six locations in the CCV. The summers of 1963 and 1965, and to a lesser degree 1982, 1994, and 2004, were cooler than normal in terms of the number of locations without a maximum temperature $>40.5^{\circ} \mathrm{C}$. Colusa had the lowest number of years with maximum temperatures $>40.5{ }^{\circ} \mathrm{C}$ during the summer, viz. 50 out of $60 \mathrm{yr}$. However, there were various $10-\mathrm{d}$ 
Table 3. Occurrence of days with maximum temperatures $>40.5^{\circ} \mathrm{C}$ and $10-\mathrm{d}$ periods with an accumulated sum of lethal temperature quotients $\left(\mathrm{ALTQ} \mathrm{Q}_{10}\right)$ $>1$ during the time span from May through October 1950-2009, at six locations in the California Central Valley. The locations were Chico (A, a), Colusa (B, b), Davis (D, d), Winters (E, e), Los Banos (G, g), and Coalinga (H, h).

\begin{tabular}{|c|c|c|c|c|c|c|}
\hline \multirow[b]{2}{*}{ Year } & \multicolumn{6}{|c|}{ Decade } \\
\hline & 1950-1959 & 1960-1969 & 1970-1979 & 1980-1989 & 1990-1999 & 2000-2009 \\
\hline 0 & $\mathrm{~A}, \mathrm{~B}, \mathrm{D}, \mathrm{E}, \mathrm{G}, \mathrm{H}$ & $\mathrm{A}, \mathrm{B}, \mathrm{D}, \mathrm{E}, \mathrm{G}, \mathrm{H}$ & $\mathrm{A}, \mathrm{B}, \mathrm{D}, \mathrm{E}, \mathrm{G}, \mathrm{H}$ & $\#, \mathrm{~B}, \mathrm{D}, \mathrm{E}, \mathrm{G}, \mathrm{H}$ & $\mathrm{A}, \mathrm{B}, \mathrm{D}, \mathrm{E}, \mathrm{G}, \mathrm{H}$ & $\mathrm{A}, \mathrm{B}, \mathrm{D}, \mathrm{E}, \mathrm{G}, \mathrm{H}$ \\
\hline 1 & $\mathrm{~A}, \mathrm{~B}, \mathrm{D}, \mathrm{E}, \mathrm{G}, \mathrm{H}$ & $\mathrm{A}, \mathrm{B}, \mathrm{D}, \mathrm{E}, \mathrm{G}, \mathrm{H}$ & $\mathrm{A}, \mathrm{B}, \mathrm{D}, \mathrm{E}, \mathrm{G}, \mathrm{H}$ & $\mathrm{A}, \mathrm{B}, \mathrm{D}, \mathrm{E}, \mathrm{G}, \mathrm{H}$ & $\mathrm{A}, \mathrm{B}, \mathrm{D}, \mathrm{E}, \mathrm{G}, \mathrm{H}$ & $\mathrm{A}, \mathrm{B}, \mathrm{D}, \mathrm{E}, \mathrm{G}, \mathrm{H}$ \\
\hline 2 & $\mathrm{~A}, \mathrm{~B}, \mathrm{D}, \mathrm{E}, \mathrm{G}, \mathrm{H}$ & $\mathrm{A}, \mathrm{B}, \mathrm{d}, \mathrm{E}, \mathrm{G}, \mathrm{H}$ & $\mathrm{A}, \mathrm{B}, \mathrm{D}, \mathrm{E}, \mathrm{G}, \mathrm{H}$ & $\mathrm{A}, \mathrm{B}, \mathrm{d}, \mathrm{e}, \mathrm{g}, \mathrm{h}$ & $\mathrm{A}, \mathrm{B}, \mathrm{D}, \mathrm{E}, \mathrm{G}, \mathrm{H}$ & $\mathrm{A}, \mathrm{B}, \mathrm{D}, \mathrm{E}, \mathrm{G}, \mathrm{H}$ \\
\hline 3 & $\mathrm{~A}, \mathrm{~B}, \mathrm{D}, \mathrm{E}, \mathrm{G}, \mathrm{H}$ & $\mathrm{a}, \mathrm{b}, \mathrm{d}, \mathrm{e}, \mathrm{g}, \mathrm{H}$ & $\mathrm{A}, \mathrm{B}, \mathrm{D}, \mathrm{E}, \mathrm{G}, \mathrm{H}$ & $\mathrm{A}, \mathrm{B}, \mathrm{D}, \mathrm{E}, \mathrm{G}, \mathrm{H}$ & $\mathrm{a}, \mathrm{b}, \mathrm{D}, \mathrm{E}, \mathrm{G}, \mathrm{H}$ & $\mathrm{A}, \mathrm{B}, \mathrm{D}, \mathrm{E}, \mathrm{G}, \mathrm{H}$ \\
\hline 4 & $\mathrm{~A}, \mathrm{~B}, \mathrm{D}, \mathrm{E}, \mathrm{G}, \mathrm{H}$ & $\mathrm{A}, \mathrm{b}, \mathrm{D}, \mathrm{E}, \mathrm{G}, \mathrm{H}$ & $\mathrm{A}, \mathrm{B}, \mathrm{D}, \mathrm{E}, \mathrm{g}, \mathrm{H}$ & $\mathrm{A}, \mathrm{B}, \mathrm{D}, \mathrm{E}, \mathrm{G}, \mathrm{H}$ & $\mathrm{A}, \mathrm{b}, \mathrm{d}, \mathrm{E}, \mathrm{g}, \mathrm{H}$ & $\mathrm{A}, \mathrm{b}, \mathrm{D}, \mathrm{e}, \mathrm{g}, \mathrm{H}$ \\
\hline 5 & $\mathrm{~A}, \mathrm{~B}, \mathrm{D}, \mathrm{E}, \mathrm{G}, \mathrm{H}$ & $\mathrm{A}, \mathrm{b}, \mathrm{d}, \mathrm{e}, \mathrm{G}, \mathrm{h}$ & $\mathrm{A}, \mathrm{B}, \mathrm{D}, \mathrm{E}, \mathrm{g}, \mathrm{H}$ & $\mathrm{A}, \mathrm{B}, \mathrm{D}, \mathrm{E}, \mathrm{G}, \mathrm{H}$ & $\mathrm{A}, \mathrm{B}, \mathrm{D}, \mathrm{E}, \mathrm{G}, \mathrm{H}$ & $\mathrm{A}, \mathrm{B}, \mathrm{D}, \mathrm{E}, \mathrm{G}, \mathrm{H}$ \\
\hline 6 & $\mathrm{~A}, \mathrm{~B}, \mathrm{D}, \mathrm{E}, \mathrm{G}, \mathrm{H}$ & $\mathrm{A}, \mathrm{B}, \mathrm{D}, \mathrm{E}, \mathrm{G}, \mathrm{H}$ & $\mathrm{a}, \mathrm{B}, \mathrm{D}, \mathrm{E}, \mathrm{G}, \mathrm{H}$ & $\mathrm{A}, \mathrm{b}, \mathrm{d}, \mathrm{E}, \mathrm{G}, \mathrm{H}$ & $\mathrm{A}, \mathrm{B}, \mathrm{D}, \mathrm{E}, \mathrm{G}, \mathrm{H}$ & $\mathrm{A}, \mathrm{B}, \mathrm{D}, \mathrm{E}, \mathrm{G}, \mathrm{H}$ \\
\hline 7 & $\mathrm{~A}, \mathrm{~B}, \mathrm{D}, \mathrm{E}, \mathrm{G}, \mathrm{H}$ & $\mathrm{A}, \mathrm{B}, \mathrm{D}, \mathrm{E}, \mathrm{G}, \mathrm{H}$ & $\mathrm{A}, \mathrm{B}, \mathrm{D}, \mathrm{E}, \mathrm{G}, \mathrm{H}$ & $\mathrm{A}, \mathrm{B}, \mathrm{D}, \mathrm{E}, \mathrm{g}, \mathrm{H}$ & $\mathrm{A}, \mathrm{b}, \mathrm{D}, \mathrm{E}, \mathrm{G}, \mathrm{H}$ & $\mathrm{A}, \mathrm{b}, \mathrm{D}, \mathrm{E}, \mathrm{G}, \mathrm{H}$ \\
\hline 8 & $\mathrm{~A}, \mathrm{~B}, \mathrm{D}, \mathrm{E}, \mathrm{G}, \mathrm{H}$ & $\mathrm{A}, \mathrm{b}, \mathrm{D}, \mathrm{E}, \mathrm{G}, \mathrm{H}$ & $\mathrm{A}, \mathrm{B}, \mathrm{D}, \mathrm{E}, \mathrm{G}, \mathrm{H}$ & $\mathrm{A}, \mathrm{B}, \mathrm{D}, \mathrm{E}, \mathrm{G}, \mathrm{H}$ & $\mathrm{A}, \mathrm{B}, \mathrm{D}, \mathrm{E}, \mathrm{G}, \mathrm{H}$ & $\mathrm{A}, \mathrm{B}, \mathrm{D}, \mathrm{E}, \mathrm{G}, \mathrm{H}$ \\
\hline 9 & $\mathrm{~A}, \mathrm{~B}, \mathrm{D}, \mathrm{E}, \mathrm{G}, \mathrm{H}$ & $\mathrm{A}, \mathrm{B}, \mathrm{D}, \mathrm{E}, \mathrm{g}, \mathrm{H}$ & $\mathrm{A}, \mathrm{B}, \mathrm{d}, \mathrm{E}, \mathrm{G}, \mathrm{H}$ & $\mathrm{A}, \mathrm{B}, \mathrm{D}, \mathrm{E}, \mathrm{G}, \mathrm{H}$ & $\mathrm{A}, \mathrm{B}, \mathrm{D}, \mathrm{E}, \mathrm{G}, \mathrm{H}$ & $\mathrm{A}, \mathrm{B}, \mathrm{D}, \mathrm{E}, \mathrm{G}, \mathrm{H}$ \\
\hline
\end{tabular}

Upper-case letters in the respective year, days with a maximum temperature $>40.5^{\circ} \mathrm{C}$ as well as 10 -d periods with an $\mathrm{ALTQ}_{10}>1$ were observed.

Lower-case letters in the respective year, only 10 -d periods with an $\mathrm{ALTQ}_{10}>1$ were observed.

\#No data available for the location Chico.

periods with an $\mathrm{ALTQ}_{10}>1$ at all locations. This means lethal temperatures for the uredinial stage of P.s. tritici were observed during all the summers of the entire period. In other words, in those $60 \mathrm{yr}$ wheat stripe rust could not possibly have over-summered at any of these locations. This is corroborated by a more detailed analysis (Table 4) of the number of days with a maximum temperature $>$ $40.5^{\circ} \mathrm{C}$ and of 10 -d periods with an $\mathrm{ALTQ}_{10}>1$ in each growing season in the period 1997-2009 at four locations in the Sacramento Valley. These results indicate that both phenomena usually occur frequently and alternately in each season until late summer, and sometimes even happen at the beginning of autumn.

In this respect, Line (1976) disagrees and argues that even though the ambient temperature in an area may be high, the temperature within a plant canopy, especially in or near irrigated fields or orchards, may be lower because of evaporative cooling and shading by plants. But the effect of shading on ambient temperature has been accounted for, since temperature records published by meteorological stations are obtained from instruments placed in a special shelter termed a Stevenson Screen, which shields them from direct radiation. Furthermore, the shelter is installed at a standardized height (base: 1.25$2.00 \mathrm{~m}$ ) above the ground because temperatures tend to increase closer to the soil surface. For evaporative cooling to be somewhat effective, irrigation must closely coincide in timing, duration, and frequency with the occurrence of extreme maximum ambient temperatures, which is unlikely to be accomplished. At any rate, if Line's (1976) argument is correct, volunteer wheat plants with viable P.s. tritici uredinia during the summer should be detected in the first place in the Colusa-Sutter area, considering that it has the fewest number of years with daily maximum temperatures $>40.5{ }^{\circ} \mathrm{C}$ in summer (Tables 3 and 4 ).

In the present context, the method of estimation of ALTQ merits critical review. Tollenaar and Houston (1967) observed the death of uredinial stripe rust lesions in susceptible wheat plants without HTAP resistance at Davis after a 10-d period (20-29 June 1964) with a mean maximum and a daily mean temperature of 32.4 and $22.3{ }^{\circ} \mathrm{C}$, respectively. Consequently, calculation of the corresponding $\mathrm{ALTQ}_{10}$ ought to yield a value $>1$. However, an $\mathrm{ALTQ}_{10}$ of 0.829 was obtained, pointing to a substantial underestimation of the lethal impact of high temperatures on stripe rust. This can be mainly attributed to the fact that with the present method of calculation the harmful effect of daily temperatures between 25 and $30{ }^{\circ} \mathrm{C}$ (Tollenaar and Houston, 1967; Tollenaar, 1985; Dennis, 1987) goes unaccounted for. The explanation for

Table 4. Last day with a maximum temperature above the lethal upper threshold temperature (40.5 $\left.{ }^{\circ} \mathrm{C}\right)$ for the uredinial stage of Puccinia striiformis f.sp. tritici, or the last 10-d period with an accumulated sum of lethal temperature quotients $\left(\mathrm{ALTQ}_{10}\right)>1$, whichever occurred last, in the respective late summer or early autumn of the years 1997-2009, at four locations in the Sacramento Valley. In parentheses, total number of days observed with $T_{\max }>$ $40.5^{\circ} \mathrm{C}$ (bold face type) and of 10 -d periods with an $\mathrm{ALTQ}_{10}>1$ (Roman face type) during the respective year.

\begin{tabular}{|c|c|c|c|c|}
\hline \multirow[b]{2}{*}{ Year } & \multicolumn{4}{|c|}{ Location } \\
\hline & Willows & Colusa & Oroville Dam & Davis \\
\hline 1997 & 21-30 Sept $(\mathbf{1} ; 6)$ & $21-30$ Sept $(\mathbf{0} ; 4)$ & 04-13 Sept $(\mathbf{1} ; 3)$ & 22 Sept-1 Oct $(3 ; 5)$ \\
\hline 1998 & 28 Aug-6 Sept $(4 ; 1)$ & 7-16 Sept $(\mathbf{5} ; 5)$ & 8-17 Sept $(7 ; 4)$ & 6-15 Sept $(\mathbf{9} ; 4)$ \\
\hline 1999 & 23 Sept-2 Oct $(1 ; 4)$ & 22 Sept-1 Oct $(\mathbf{1} ; 4)$ & 24 Aug-2 Sept $(\mathbf{1} ; 2)$ & 23 Sept-2 Oct $(4 ; 4)$ \\
\hline 2000 & 23 Sept-2 Oct $(\mathbf{5} ; 4)$ & 12-21 Sept $(2 ; 4)$ & 12-21 Sept $(\mathbf{1} ; 5)$ & 13-22 Sept $(2 ; 5)$ \\
\hline 2001 & 20 Sept: $40.6^{\circ} \mathrm{C}(3 ; 4)$ & 2 Oct: $40.6^{\circ} \mathrm{C}(6 ; 1)$ & 29 Aug-7 Sept $(4 ; 6)$ & 29 Aug-7 Sept $(\mathbf{4} ; 4)$ \\
\hline 2002 & 18-27 Sept $(2 ; 4)$ & 18-27 Sept $(\mathbf{1} ; 5)$ & 18-27 Sept $(\mathbf{3} ; 5)$ & 19-28 Sept $(\mathbf{3} ; 4)$ \\
\hline 2003 & $20-29$ Sept $(\mathbf{4} ; 5)$ & 30 Aug-8 Sept $(\mathbf{3} ; 6)$ & $15-24$ Sept $(4 ; 3)$ & $19-28$ Sept $(4 ; 4)$ \\
\hline 2004 & 9-18 Sept $(\mathbf{0} ; 5)$ & 29 Aug-7 Sept $(\mathbf{0} ; 4)$ & 8-17 Sept $(\mathbf{1} ; 7)$ & na* \\
\hline 2005 & 27 Aug-5 Sept $(2 ; 6)$ & 26 Aug-4 Sept $(3 ; 6)$ & 29 Aug-7 Sept $(4 ; 5)$ & 27 Aug-5 Sept $(4 ; 4)$ \\
\hline 2006 & 5-14 Sept $(8 ; 7)$ & 30 Aug-8 Sept $(\mathbf{3} ; 4)$ & 5-14 Sept $(\mathbf{1 0} ; 6)$ & 30 Aug-8 Sept $(7 ; 3)$ \\
\hline 2007 & na* & 2-11 Sept $(\mathbf{0} ; 5)$ & $2-11$ Sept $(2 ; 4)$ & $2-11$ Sept $(4 ; 6)$ \\
\hline 2008 & 2-11 Sept $(7 ; 3)$ & 6-15 Sept $(3 ; 7)$ & $7-16$ Sept $(7 ; 4)$ & 23 Sept-2 Oct $(9 ; 7)$ \\
\hline 2009 & 27 Sept: $40.6^{\circ} \mathrm{C}(2 ; 7)$ & 23 Sept-1 Oct $(2 ; 5)$ & na* & 16-25 Sept $(\mathbf{1} ; 3)$ \\
\hline
\end{tabular}

na: no data available. 
this omission is that detailed information to quantify the lethal impact of temperatures between 25 and $30{ }^{\circ} \mathrm{C}$ on stripe rust is lacking and therefore, although incorrectly, this effect has been considered here to be non-existent. In sum, the temperature conditions in the CCV during the summer are substantially more pernicious for P.s. tritici than those estimated with Equations [5] and [6].

The prolonged adverse environmental conditions for uredinia and uredinio-mycelium of P.s. tritici during the summer in the CCV imply that the initial stripe rust infections by urediniospores during the next growing season must originate from exogenous sources. There are two possible relatively close locations, the first being the extensive area at an elevation above $1800 \mathrm{~m}$ in the Sierra Nevada Mountains, covered with wild grasses permanently infected with P.s. tritici. The other is the neighboring Tulelake Basin at the northern state-line, with spring-sown wheat fields at an altitude of 1300 m (Tollenaar and Houston, 1967), and the infected volunteer wheat plants in the state of Oregon (Shaner and Powelson, 1973) could also be involved. However, the distribution and relative severity of wheat stripe rust races from 2000 to 2007 in California as compared to Oregon (Chen et al., 2010) lends no support to this proposition. The Californian coastal zone bordering the Pacific Ocean is another option for over-summering infection sources. Urediniospores from infected native grasses growing near the coast (Tollenaar and Houston, 1967; Line, 2002) and also from infected wheat in spring/summer breeding nurseries and wheat cover crops in the Salinas Valley/ Monterrey area (L. F. Jackson, University of California, Davis, California, USA; personal communication) could be carried with eastward winds into the CCV via the strait connecting the Susan Bay/Sacramento-San Joaquin Delta with the San Francisco Bay.

Finally, the possibility of a third, endogenous source of inoculum for initial stripe rust infections cannot be precluded, that is to say, the accidental presence in the $\mathrm{CCV}$ of stripe rust-susceptible barberry (Berberis spp.), the alternate host of P.s. tritici (Jin, 2011; Jin et al., 2010) in the vicinity of threshed wheat fields or volunteer wheat plants with telia of P.s. tritici on their vegetative parts. Here, the teliospores that have not lost their viability during the high summer temperatures could constitute a source of primary inoculum with the germination of these spores under moderate environmental conditions in autumn, leading to the development of pycnia and, consequently, aecia in the alternate host. Obviously the aeciospores, in turn, could initiate a stripe rust infection in wheat. However, no specific information is presently available on this matter.

\section{CONCLUSIONS}

Exhaustive use of molecular analyses in the identification of the stripe rust isolates collected in all the aforementioned parts of California will eventually furnish the essential details on the role of these areas as primary infection sources of P.s. tritici for commercial wheat plantings in the California Central Valley.

\section{ACKNOWLEDGEMENTS}

The author wishes to thank Lee F. Jackson, University of California, Davis, California, USA; Roland F. Line, Washington State University, Pullman, Washington, USA, and Ricardo Madariaga, Instituto de Investigaciones Agropecuarias, Chillán, Chile, for their comments and suggestions.

Supervivencia estival de la roya estriada (Puccinia striiformis f.sp. tritici) del trigo en el Valle Central de California: Estudio de caso. Para estudiar la supervivencia estival de la roya estriada (Puccinia striiformis f.sp. tritici) del trigo (Triticum aestivum L.) en el Valle Central de California (CCV), los registros de temperatura de varios lugares en el CCV durante el período 1950-2009 fueron examinados por la ocurrencia de altas temperaturas, cuyos efectos son letales para las uredinia y el uredinio-micelio de este hongo. El umbral de temperatura alta letal para el estado uredinial de P.s. tritici, estimado en 40,5 ${ }^{\circ} \mathrm{C}$ en base de datos publicados en la literatura, y la suma acumulada durante 10 días consecutivos de los respectivos coeficientes de temperaturas letales $\left(\mathrm{ALTQ}_{10}\right)$, representando el efecto letal parcial de las temperaturas diarias entre 30 y $40,5^{\circ} \mathrm{C}$ para el estado uredinial de P.s. tritici, fueron usados para determinar su impacto letal. Los resultados indican que en estos 60 años el estado uredinial de P.s. tritici no podría haber sobrevivido el verano en ninguno de los lugares estudiados del CCV. Esto deja a las montañas de la Sierra Nevada junto con la Cuenca de Tulelake y la zona bordeando al Océano Pacífico como las únicas dos áreas en California con condiciones ambientales apropiadas para la supervivencia estival del estado uredinial de la roya estriada. Por tanto, se supone que el inóculo para las infecciones iniciales de P.s. tritici en las sementeras de trigo en el CCV durante la siguiente época de cultivo proviene de uno o ambos sectores. Aunque una posible tercera fuente de inóculo para las infecciones iniciales de la roya estriada en el CCV también podría estar involucrada. Es decir, la eventual existencia de telios con teliosporas viables de P.s. tritici en otoño sobre la paja de las sementeras de trigo trilladas o sobre las plantas de trigo voluntario en el CCV, en combinación con la casual presencia de Berberis susceptible a la roya estriada en su cercanía pudiera conducir a la generación de fuentes alternativas y endógenas de inóculo en el CCV.

Palabras clave: roya estriada, epidemiología, temperatura letal, Triticum aestivum. 


\section{LITERATURE CITED}

Chen, X.M. 2005. Epidemiology and control of stripe rust (Puccinia striiformis f. sp. tritici) on wheat. Canadian Journal of Plant Pathology 27:314-337.

Chen, X.M., M. Moore, E.A. Milus, D.L. Long, R.F. Line, D. Marshall, and L. Jackson. 2002. Wheat stripe rust epidemics and races of Puccinia striiformis f.sp. tritici in the United States in 2000. Plant Disease 86:39-46.

Chen, X.M., L. Penman, A. Wan, and P. Cheng. 2010. Virulence races of stripe Puccinia striiformis f.sp. tritici in 2006 and 2007 and development of wheat rust and distributions, dynamics, and evolutionary relationships of races from 2000 to 2007 in the United States. Canadian Journal of Plant Pathology 32:315-333.

Dennis, J.I. 1987. Effect of high temperatures on survival and development of Puccinia striiformis on wheat. Transactions of the British Mycological Society 88:91-96.

Jin, Y. 2011. Role of Berberis spp. as alternate hosts in generating new races of Puccinia graminis and P. striiformis. Euphytica 179:105-108
Jin, Y., J. Szabo, and M. Carson. 2010. Century-old mystery of Puccinia striiformis life history solved with the identification of Berberis as an alternate host. Phytopathology 100:432-435.

Line, R.F. 1976. Factors contributing to an epidemic of stripe rust on wheat in the Sacramento Valley of California in 1974. Plant Disease Reporter 60:312-316.

Line, R.F. 2002. Stripe rust of wheat and barley in North America: A retrospective historical review. Annual Review of Phytopathology 40:75-118.

Shaner, G., and R.L. Powelson. 1973. The over-summering and dispersal of inoculum of Puccinia striiformis in Oregon. Phytopathology 63:13-17.

Tollenaar, H. 1985. Uredospore germination and development of some cereal rusts from south-central Chile at constant temperatures. Phytopathologische Zeitschrift 114:118-125.

Tollenaar, H., and B.R. Houston. 1967. A study on the epidemiology of stripe rust, Puccinia striiformis West., in California. Canadian Journal of Botany 45:291-307.

Zeng, S.M., and Y. Luo. 2006. Long-distance spread and interregional epidemics of wheat stripe rust in China. Plant Disease 90:980-988. 